Orientalia Christiana Cracoviensia 5 (2013), s. 51-61

DOI: http://dx.doi.org/10.15633/ochc.1032

Corina Petronela Panait

École Pratique des Hautes Études, Paris

\title{
Orthodox Icons in Romanian State Schools: Symbols of Romania's Orthodox Identity?
}

Romania, like many other European countries, evokes its religious tradition in the coat of arms on the flag and in the national anthem. Another way to express Romanian Christian Orthodoxy is for school communities to display orthodox icons in classrooms. Their place is either central, above the blackboard, or, in most of the cases, east-oriented or even at the back of the classroom. No matter their place of exhibition, the icons have the same role: pedagogic material for religion classes and a symbol of the community's belief. The presence of such symbols was attested in schools in 1948 by communist documents having the purpose to replace them with the dictator's portrait. The next time icons appeared in schools was after the fall of communism, when the portrait of the dictator was removed and icons to restored express the end of religious constraints.

If in 1998 the icons displayed at the University of Bucharest were taken down on demand of several students, in state high-schools there was no complaint against their presence until 2001, when the Christian Orthodox Emil Moise became the philosophy teacher of an art high school in Buzău where the icons abounded.

Considering this contestation of icons I investigate if the icons can still be considered as a symbol of Romania's Orthodox identity. To answer this question I will first briefly introduce the main arguments exchanged in the debate over the presence of icons and afterwards some important moments in the history of Christianity in Romania. With these instruments I intend to point out the references to Christianity, identity and religious identity that are present in the debate.

\section{The debate over the presence of Orthodox icons in schools}

At the sight of the myriad of Orthodox icons displayed in his high-school, Mr. Moise lodged a complaint first to his school council and to his departmental 
inspectorate of education that the presence of Orthodox icons in the school where he taught philosophy was a discrimination against those who did not share the belief embodied by the icons. So, he recomended that the icons should be removed. Since the local authorities rejected his complaint, because the school was an art school and icons were also an object of study, he decided to go in front of the National Council against Discrimination $(\mathrm{NCaD}) .{ }^{1}$

Thus the debate was initiated in November 2006 through Emil Moise's plea $^{2}$ in front of the $\mathrm{NCaD}$. At this point his request became broader in that he complained about the presence of Orthodox icons in all the state schools in Romania, not only about the icons in the high school where he taught. In response to his complaint, the $\mathrm{NCaD}$ answered that in the case of the art school the sentence of the Ploiesti Court of Appeal - which decided that icons should remain in classrooms due to the school's specialization - must be respected. As far as the matter concerned all the other schools in Romania, the Council judged that the uncontrolled presence of icons in public institutions of education was an infringement of the state's religious neutrality and could lead to discriminatory situations. In order to prevent such situations, the $\mathrm{NCaD}$ issued a recommendation to the Ministry of Education through which it was advised to enact a rule so that the icons were removed from schools except for the religion class. ${ }^{3}$

As a reaction to Mr. Moise's action, the Ministry of Education and the Secretary of State for Cults issued official statements by which the spontaneous act of displaying icons in state schools was described as a manifestation of the school community's beliefs ${ }^{4}$. In this way the identity question was introduced into a debate started as a defense of pupils' rights against the abuses of the presence of icons. Although the supporters of icons did not use the terms national identity or collective identity, they resorted to terms like tradition, spirituality and cultural heritage, which are elements of a collective's identity. But what do this tradition, spiritual and cultural heritage consist of?

${ }^{1}$ The NCaD is a state autonomous authority under parliamentary control dealing with discrimination through: prevention, mediation, investigation, monitoring and special assistance to discrimination cases. (for more details see the $\mathrm{NCaD}$ site http://www.cncd.org.ro/).

${ }^{2}$ The text of the petition is available in Romanian on the site of the NGO Solidarity for the freedom of conscience http://www.humanism.ro/articles.php?page=62\&article=177. Emil Moise was an initiator and director of programs in this NGO and received its full support all through the debate. E. Simionescu, Prezenta simbolurilor religioase in scolile publice - un interviu ("The Presence of Religious Symbols in Public Schools - an Interview")., "Viata si Sanatate" № 161-162 (2006). As of August 2009 Emil Moise was appointed president of the NGO, when Remus Cernea, the former president, made a bid for the presidency of Romania.

3 “The Decision” № 323 (2006) [21.11] of NCaD is not available online, but can be asked for by e-mail at http://www.cncd.org.ro/contact/.

${ }^{4}$ The press release of Mircea Muresan, spokesperson of the Ministry of Education and Research is available on line in Romanian only at http://administraresite.edu.ro/index.php/articles/7103. 


\section{Remembering the Christian past of Romania}

In order to answer this question I have chosen some historical moments that are usually referred to when we speak about the Christian tradition in Romania. Christianity was brought to Romania in the first centuries of our era. ${ }^{5}$ Church historians, on the basis of Eusebius of Caesarea's chronicles, say that it was the Apostle Andrew who passed through Romania's eastern region, Dobruja. ${ }^{6}$ That makes for a two thousand year tradition of Christianity on Romanian territory. Later on, after the fall of Byzantium, the princes of Romanian states became the protectors of Christian Orthodoxy in their states but also of the Holy Mountain monasteries and of the Patriarchate of Constantinople. ${ }^{7}$ One of those princes is known to have carried icons in his battles against invaders ${ }^{8}$ and to have erected a church after each victory. Several centuries later, on the eve of the 1848 revolution, Andrei Muresanu wrote a poem that nowadays is Romania's national anthem. In his poem, Muresanu summons the Romanian people to awaken from their deathlike sleep, to follow the example of the great Romanian princes who fought for the unity and the liberty of Romanians, having the Christian faith as ally in their struggle. ${ }^{9}$

A century later, we find a cultural association called the "Book under the icon" initiating a literacy campaign in the rural areas of Dobruja and North Moldavia. With the purpose of promoting reading in Romanian, the association distributed donated books through the local church after being blessed by the priest. The peasants reverently received the books from the hand of the priest

${ }^{5}$ Christianity first reached Dacia (roughly coextensive with modern Romania) under the Roman Empire at least as early as the 4th century AD. By the late 9th century, the Vlachs (i.e. ethnic Romanians) appear to have accepted a Slavonic liturgy and Bulgarian ecclesiastical jurisdiction. Romanian Orthodox Church, [in:] Encyclopcedia Britannica Online, http://www. britannica.com/EBchecked/topic/508618/Romanian-Orthodox-Church.

${ }^{6}$ This fact is supported also by a toponym lasting to our days as the cave of Saint Andrew, the spring of St Andrew. Besides Eusebius of Caesarea, the church fathers like Hypolites the Roman, Origen and Tertullian testify in their works about the preaching of Saint Andrew in Scythia minor, a region including present day Dobruja. J. Zeiller, Les origines chrétiennes dans les provinces danubiennes de L'Empire romain, Paris 1918, p. 29.

${ }^{7}$ This status of Romanian princes determined historian Nicolae Iorga to assert that Romanian principalities were Byzantium after Byzantium.

${ }^{8}$ Stephen the Great (1435-1504), in Romanian: Stefan cel Mare, voivod (prince) of Moldavia (1457-1504), who was renown in Europe for his long resistance to the Ottoman Turks, see Stephen, [in:] Encyclopcedia Britannica Online, http:/www.britannica.com/EBchecked/topic/565404/ Stephen. He was declared a saint by the Romanian Orthodox Church in June 1992. For details see the site dedicated to Stephen the Great by the Monastery of Putna, one of the monasteries erected under his reign http://www.stefancelmare.ro/Tomos-s2-ss13.htm.

${ }^{9}$ For an English version of the Romanian National anthem see the site of the NGO promoting information on the European states and their minorities: http:/www.eurominority.eu/version/ fra/minority-detail.asp?id_minorities $=198$. 
and kept them wrapped in paper under an icon. This action points out the role of icons as protectors of culture.

In fact, icons could be found also in Romanian state schools in the year 1948, the year when the communist regime ordered them to be removed and replaced with the communist president's portrait. After the fall of communism people felt the need to restore Orthodox icons in order to express the end of repression and return to liberty, including freedom of religious manifestation. About twelve years after that spontaneous return of icons in schools, the defender of pupils and teachers holding other beliefs than the Orthodox Christian one, Emil Moise, questions the legitimacy of displaying the symbol of one faith in Romanian state schools.

\section{Two models of collective identity}

Moise argues that icons do not express Romanian culture and spirituality, the Christian tradition in Romania is represented by a cross not by an icon in the state's coat of arms. If the icon had represented Romanian cultural identity, then Romanian people would have been religious people and the Romanian state a religious state as in Islamic countries. So, the condition to consider icons as a feature of the Romanian people's identity is its religiosity expressed not in the percentage of declared Christians, but in the laws of the Romanian state and in the behaviour of Orthodox Christian believers.

On the other hand, although representatives of different religious cults in Romania cannot affirm that icons express their identity (because icons pertain only to the Orthodox cult), they still feel that the presence of Orthodox icons is a guarantee of religious freedom for all Romanian believers. ${ }^{10}$ In this way, icons lose their specific religious content and gain a general meaning of freedom of religious expression for all. So, while for Orthodox Christians the icons carry an identity and liberty meaning, for other cults, identity cannot be found, but a common meaning of liberty would legitimize the icons' presence in state schools.

Moreover, the Romanian Orthodox Church and a leader of the teachers' union have emphasized the fact that icons express the religion of the majority of Romanians. To that Emil Moise and his party replies that it is an abuse to suggest that a specific religion is the religion of all Romanians, as there are also atheists or other faiths in Romania. So, for them, the best choice for having an

${ }^{10}$ It is the removal of icons that worries the Muslim Mufti Bagas Sanghirai, not their presence. If Orthodox icons are removed, this is a warning that all other religions will be cast out of Romanian society. To read the complete statements in Romanian of the representatives of the cults recognized in Romania see the entry Cultele din România susţin necesitatea păstrării simbolurilor religioase în şcoli, ("The Cults of Romania maintain the need to keep religious symbols in schools") http://www.salvati-icoanele.info/2006/11/29/ pozitia-reprezentantilor-unor-culte-privind-simbolurile-religioase-in-scoli. 
equal treatment for all is to remove icons from schools, so that discrimination may be prevented.

As we can notice, two distinct identities are being shaped by each part in the debate on the presence of icons in state schools: the supporters of icons stress the Orthodox identity of the majority of Romanians, while the opposing party stresses a heterogeneous identity in Romania due to the difference of religious affiliation. In addition, the supporters of icons in schools seem to impose the Orthodox identity of the majority to all Romanians by displaying an orthodox symbol in public schools. However, the supporters always start their discourse by stressing the spontaneous movement of putting icons in classrooms from where the Communists took them.

In fact, icons are not present everywhere. A thorough study about icon frequency in classrooms is not yet available. I have experienced myself such diversity in high school, where some classrooms had one icon while many others had none. ${ }^{11}$ In fact, I guess that no debate took place before the display of icons in schools, so that no one can say that the Orthodox imposed icons over one minority who would have protested. And until Moise no complaint over their presence was made. ${ }^{12}$ But now that the question has been raised, more attention will be paid to the act of exhibiting Orthodox symbols in state schools.

With regard to the state institutions, the Ministry of Education, Research and Innovation, ${ }^{13}$ the Higher Court of Cassation and Justice (HCCJ), ${ }^{14}$ members of the parliamentary Commission on Education ${ }^{15}$, all have expressed the right of

${ }^{11}$ Differences may exist from school to school and from region to region. I studied in a theoretical high school in Călăraşi, a south-south-eastern Romanian city near the border with Bulgaria. Emil Moise's complaint is based on his experience as a teacher in an arts high school in Buzău, in the central-east part of Romania.

${ }^{12}$ In 1998 a debate was started by three philosophy students who opposed a project lead by a Christian Orthodox student association, ASCOR, wishing to construct an Orthodox chapel in the University campus and to expose Orthodox icons in all the lecture halls of the same campus. The Rectorate pressured by the opposing demands of both sides chose not to approve neither the project of construction, nor the exhibition of orthodox icons. (C. Ghinea, Ateii iconoclaşti cu care aş muri de gît, "Dilema Veche” 16 February 2007 № 158, http://dilemaveche.ro/sectiune/ tema-saptamanii/articol/iateii-iconoclastii-cu-care-as-muri-de-git).

${ }^{13}$ The name mentioned in the article is the ministry's present denomination. At the time of the debate the ministry of education was called the Ministry of Education, Research and Youth, as it appears in the decision of the HCCJ in June 2008, and Ministry of Education and Research, as it appears in the decision taken by the NCaD in November 2006.

${ }^{14}$ The decision № 2393 of the HCCJ pronounced on June 11, 2008, closed the debate by accepting the Ministry's of Education request to overrule the recommendation of the NCaD.

${ }^{15}$ Irinel Popescu, member of the Conservative Party, Olguta Vasilescu, member of the Greater Romania Party, are some of those who expressed their support for the decision of the community. See article: Comisia de Invăţămînt a Camerei Deputatilor respinge interzicerea icoanelor in scoli, "Ziarul de Iasi", 21/12/2006, http://www.ziaruldeiasi.ro/invatamant/ comisia-de-invatamint-a-camerei-deputatilor-respinge-interzicerea-icoanelor-in-scoli ni $46 \mathrm{rm}$. 
local communities to decide whether to exhibit or not Orthodox icons in schools. In this way the Romanian state through all its powers (executive, legislative, and judiciary) has recognized that its heterogeneous population ${ }^{16}$ - with regard to religion - cannot be imposed upon via an administrative rule from the top of the hierarchy, but needs to find its own way to express religious affiliation. In this way there is no collective identity imposed by the state, each school's community (pupils, parents and teachers) being allowed to decide if the symbol of Orthodoxy needs to be displayed or not, so that it can embody a feature of the community's identity.

As result of the state's democratic decision to let the school community decide whether to display Orthodox icons or not, the local communities are not given any guidance on how to make such a decision. So, the communities will have to forge their own position regarding icons or to choose from the two positions expressed in the debate.

These two standpoints over the legitimacy of exposing icons in state schools expressed in the debate can be translated into two different manners of conceiving collective identity.

The first manner is presented by the supporters of icons who understand collective identity as based on tradition, history and culture, although it cannot include all the population, as various minorities have a different cultural heritage. However, they do not pretend that this kind of identity is that of all Romanians, but that of a majority of Romanians.

The second manner of conceiving collective identity pertains to those opposing the exhibition of icons, who are the partisans of a reduced and all-inclusive identity. Their suggestion is to eliminate the particularities of the majority of Romanians so that all the minorities can feel included in the civic identity based on human rights. In this second case one cannot speak of a nation's identity, because the opponents of icons do not stress the common history or cultural heritage of Romanians, but they emphasize only the rights of Romanian citizens. All Romanians must enjoy the same rights, they must be equally treated by the state, and the state must not allow for any religious manifestation that might offend those citizens holding different beliefs.

Besides this twofold understanding of Romanians collective identity, we can perceive some elements that point to different identity for each party. For instance, the supporters of icons identify themselves not only through the Orthodox element. From their perspective over the debate another identity feature

${ }^{16}$ Due to foreign occupation in Transylvania the number of Catholics and Protestants is important, while in Dobruja a Muslim community peacefully lives among Orthodox. And it seems that both Muslim and Orthodox symbols are present in some schools (according to the Orthodox Patriarchate spokesman, Atac la icoane ("Icons under attack"), "Ziua" Issue 3787, Wednesday, 22 November 2006, http://www.ziua.net/display.php?data=2006-11-22\&id=211622). 
is being forget. Designating the opposition to icons as specific to communism, the supporters of icons considered themselves anti-communist, while Mr. Moise is perceived as continuing the policy of the communists, who were the only ones to have ever removed icons from state schools.

However, Moise and his supporters do not act in the name of the communist atheistic doctrine, but in the name of human rights, equal treatment and the neutrality of the state towards its citizens. And, above all, Mr. Moise does not oppose the Orthodox belief and its manifestation. All that he asks for is that this particular belief be confined to the private sphere or to be expressed in public, but not in public institutions of the state, which must be religiously neutral. Only the effect of his action could have been compared to the communist regime: if the complaint of Mr. Moise had succeeded, then the icons would have been taken out of schools, just as in the time of the communists. After all, Mr. Moise's action did not succeed, yet only his intention and the thought of it recalled Romanians the recent fifty years of communism, when religious expression was not free.

The communist/anti-communist dichotomy, as the pro icons camp understands the two positions in the debate, is supported also by the fact that among the NGO's backing the supporters of icons in state schools, we can count several organizations of revolutionaries and anti-communist associations. ${ }^{17}$

To the identity antagonism communists versus anti-communists, the two parties of the debate over the presence of icons in school seem to add another feature to their collective identity, but this time also only in the discourse of the party supporting the presence of icons. Seeing that Mr. Moise used in his speech the principle of state neutrality understood as requiring the removal of icons, the supporters of icons immediately thought of laicity and none other than French laïcité. Neither Mr. Moise, nor his supporters mentioned the term in their discourse, but the supporters of icons felt that the proposition of Mr. Moise would have better fitted French society. So, in this interpretation of the supporters of icons, Mr. Moise appears as the advocate of some foreign practices that do not fit the Romanian context and thus seem to be a foreign method without roots in Romanian culture; in this way laïcité would appear to be a recipient without content.

${ }^{17}$ By the end of the year 2006 the Coalition for the Respect of Religious Feelings was founded around two main NGOs supporting the presence of icons. Thus, in addition to Civic Media and the Pro-Vita association an additional 148 institutions and NGOs of Romanians from all over the world declared their support for the action of fighting in justice the recommendation of $\mathrm{NCaD}$. See the entry $C N C D$ contestat de 150 de institutii si organizatii neguvernamentale ("NCaD contested by 150 institutions and NGOs") on the Civic Media site: http://civicmedia. ro/acm/index.php?option $=$ com_content $\&$ task $=$ view $\&$ id $=38 \&$ Itemid $=93$ 
In fact, the word laïcité is not used in the Romanian constitution, but neutrality is not used either. The term neutrality is just an interpretation of the constitutional text. What the Romanian Constitution mentions in Article 29 is the freedom of organization and of religious activity of the recognized cults, and their independence in relation to the state. This is where the neutrality of the state manifests itself, in the fact that it does not interfere with the activity of any cult in Romania. On the other hand, the same article specifies that the state supports the religious assistance of cults in the army, in hospitals, prisons, homes, and orphanages ${ }^{18}$. So, the identity opposition, in the view of icon supporters, between them and the camp of Mr. Moise is enlarged by adding to the opposition communist/anti-communist another opposition: that between the defendants of local values and tradition, which could be called autochthons and the advocates of a foreign model, which does not fit to the Romanian state, which could be called westernizers. ${ }^{19}$

However, in comparison to the communist/anti-communist dichotomy, the opposition between those willing to adopt western culture and autochthons does not give a full account of the position of the two camps. Being in favour of the display of icons as a symbol of Romanian culture, the autochthonism supporters of icons appeal also to the example of west European countries in order to stress the legitimacy of exposing the symbol of a country's religious tradition. In the westernizer camp against the icons in state schools, we can see that the international declaration of human rights is not the only document brought forward as a juridical argument. The Romanian constitution is also cited as well as the law on education. The same camp shows the icons as a possible expression of the right-wing extremism in which some Romanian intellectuals and clergy men were involved in the 1930s. Thus the opposition autochthons versus westernizers is blurred by the mingled references to Romania and the

\footnotetext{
${ }^{18}$ Art 29 of the Romanian Constitution [Religion]. (1) Freedom of thought, opinion, and religious beliefs may not be restricted in any form whatsoever. No one may be compelled to embrace an opinion or religion contrary to his own convictions. (2) Freedom of conscience is guaranteed; it must be manifested in a spirit of tolerance and mutual respect. (3) All religions shall be free and organized in accordance with their own statutes, under the terms laid down by law. (4) Any forms, means, acts, or actions of religious enmity shall be prohibited in the relationships among the cults. (5) Religious cults shall be independent from the State and shall enjoy support from it, including the facilitation of religious assistance in the army, in hospitals, prisons, homes, and orphanages. (6) Parents or legal tutors have the right to ensure, in accordance with their own convictions, the education of the minor children whose responsibility devolves on them. http://www.servat.unibe.ch/icl/ro00000_html

${ }^{19}$ I have taken up the dichotomy from an essay by Sorin Antohi (Les Roumains pendant les années 90 - Géographie symbolique et identité sociale, [in:] Imaginaire culturel et réalité politique dans la Roumanie moderne: le stigmate et l'utopie - essais, Paris-Montréal 1999, p. 276-281) who referred to two different manners of modernizing Romania by imitating the western countries or by developing traditional Romanian features.
} 
western civilization present in both camps. But, if we consider only the main argument of each camp - that of exhibiting icons as a symbol of Romanian culture and that of not displaying icons due to the right of freedom of conscience - the opposition autochthons versus those willing to adopt western culture remains meaningful.

Also in opposition to a western way of conceiving the public space, Ilona Déneş ${ }^{20}$ argues that Christian Orthodoxy does not conceive public space as separated from the private. In this key of interpretation the debate over the presence of icons becomes an absurd dialogue of deaf people. Nevertheless, this way of apprehending the two positions in the debate would lead to an Orthodox impregnated view of the supporters of icons. However, the official statements are centred not on the Orthodox doctrine ${ }^{21}$, but on the constitutional right to express one's belief, on the majority of Orthodox Romanian and also on the free choice of each community to manifest its belief. With this kind of arguments, I guess the pro-icon camp is rather situated in an articulated discourse based on non-dogmatic and democratic arguments.

\section{Conclusions}

As we have seen, the simple question of whether to display or not an orthodox icon in Romanian state schools, has raised discourses where identity terms are not included but where identity features and representations fully abound. It is interesting that the party opposing the exhibiting of the icons does not define any specific identity, it is because $\mathrm{M}$. Moise and his team are the advocates of human rights which are as universal as they can be. We find most of the references to identity, to Orthodoxy and anti-communism in the discourse of the party supporting the presence of icons in Romanian state schools.

The debate over the presence of the icons reveals one obvious element of identity for the majority of Romanians: Orthodoxy. The two other elements of self-definition: anti-communism and autochthonism appear at first as attributes of the pro-icon party. If we think that those who displayed the icons are also pro-icon although not involved in the debate, we can also extend the same attributes to them. They all spontaneously displayed icons to express the end of communism and the beginning of liberty.

${ }^{20}$ I. Déneş, The Icon of Romanian Identity Reflections on the Public Debate about Religious Symbols in Romanian Schools, "EuroPOLIS - Journal of Political Analysis and Theory" 4 December 2008, pp. 330-349.

${ }^{21}$ Except for one affirmation of "only the devil is scarred by the icons", D. C. Şontică, Doar dracul fuge de icoane si de tamaie ("Only the devil is scarred by the icons and incense"), "Jurnalul National" 25/11/2006 http://www.jurnalul.ro/stire-observator/doar-dracul-fuge-deicoane-si-de-tamaie-7118.html. 
In what concerns the 'opposition' party, they do not identify themselves as being anti-communist or communist, they simply defend the human rights of a minority, in the name of the universal quality of Romanian citizenship. In this way they define themselves as simple Romanian citizens asking for their rights. The characteristics of westernizers and communist are those attributed to them by the supporters of the icons, which they deny.

Having seen that the presence of Orthodox icons reveals different types of identity we cannot conclude on the existence of an Orthodox identity for all Romanians. The opponents deny any identity content, the other cults invest icons with the symbolism of religious liberty for all, but for many of the Romanians, the icons in schools remain an expression of Romania's religious and cultural tradition.

\section{Abstract}

The article refers to the debate over the presence of the Orthodox icons in the Romanian state schools which, after the fall of communism in Romania, replaced the dominant portraits of the dictator. Answering the question whether they might be considered as a symbol of Orthodox identity some important moments from the history of Christianity in Romania are analysed. The article presents also the main points of the proponents and opponents in the discussion over the icons in the context of broader Romanian identity.

\section{Keywords}

Romania; Orthodoxy; icons; schools; identity

\section{References}

Antohi S., Les Roumains pendant les années 90 - Géographie symbolique et identité sociale, [in:] Imaginaire culturel et réalité politique dans la Roumanie moderne: le stigmate et l'utopie - essais, Paris-Montréal 1999, pp. 276-281.

Atac la icoane ("Icons under attack”), “Ziua” 22 November 2006 no. 3787, http://www.ziua. net/display.php?data=2006-11-22\&id=211622.

CNCD contestat de 150 de institutii si organizatii neguvernamentale ("NCaD contested by 150 non-governmental institutions and organisations") on Civic Media site: http:// civicmedia.ro/acm/index.php?option=com_content\&task=view\&id=38\&Itemid=93.

Comisia de Invatamint a Camerei Deputatilor respinge interzicerea icoanelor in scoli, "Ziarul de Iasi", 21/12/2006, http://www.ziaruldeiasi.ro/invatamant/ comisia-de-invatamint-a-camerei-deputatilor-respinge-interzicerea-icoanelor-in-scoli ni46rm.

Constitution of Romania, http://www.servat.unibe.ch/icl/ro00000_html

Cultele din România susţin necesitatea păstrării simbolurilor religioase în şcoli ("The Cults of Romania sustain the necessity of keeping religious symbols in schools"), http://www.salvati-icoanele.info/2006/11/29/pozitia-reprezentantilor-unor-culte-privind-simbolurile-religioase-in-scoli.

Decision $n^{\circ} 323 / 21.11 .2006$ of $\mathrm{NCaD}$.

Decision $n^{\circ} 2393$ of the HCCJ pronounced on June 11, 2008. 
Déneş I., The Icon of Romanian Identity Reflections on the Public Debate about Religious Symbols in Romanian Schools, "EuroPOLIS - Journal of Political Analysis and Theory" 4 December 2008, pp. 330-349.

Ghinea C., Ateii iconoclaşti cu care aş muri de gît, "Dilema Veche” 16 February 2007 № 158, $\mathrm{http} / / /$ dilemaveche.ro/sectiune/tema-saptamanii/articol/iateii-iconoclastii-cu-care-as-muri-de-git. http://www.stefancelmare.ro/Tomos-s2-ss13.htm (Site dedicated to Stephen the Great by the Monastery of Putna, one of the monasteries erected under his reign).

Moise E., Petiţia adresată Consiliului Naţional pentru Combaterea Discriminării, Privind retragerea simbolurilor religioase din unităţile publice de invățământ ("Petition addressed to the $\mathrm{NCaD}$ concerning the withdrawal of religious symbols form the public schools"), 13 November 2006, http://www.humanism.ro/articles.php?page=62\&article=177.

Muresan M., Prezenţa simbolurilor religioase în şcoli trebuie să fie decisă decomunitate, de părinţii elevilor şi, nu în ultimul rând, de şcoală ("The presence of religious symbols in schools must be decided by the community, by the pupil's parents and also by the school"), http://administraresite.edu.ro/index.php/articles/7103.

NCaD site http://www.cncd.org.ro/

Romanian National anthem, English version http://www.eurominority.eu/version/fra/ minority-detail.asp?id_minorities $=198$.

Romanian Orthodox Church, [in:] Encyclopcedia Britannica Online, http://www.britannica. com/EBchecked/topic/508618/Romanian-Orthodox-Church.

Simionescu E, Prezenta simbolurilor religioase in scolile publice - un interviu, "Viata si Sanatate" 2006 № 161-162.

Şontică D. C., Doar dracul fuge de icoane si de tamaie ("Only the devil is scarred by the icons and incense"), "Jurnalul National” 25 November 2006, http://www.jurnalul.ro/ stire-observator/doar-dracul-fuge-de-icoane-si-de-tamaie-7118.html.

Stephen, [in:] Encyclopcedia Britannica Online, http:/www.britannica.com/EBchecked/ topic/565404/Stephen.

Zeiller J., Les origines chrétiennes dans les provinces danubiennes de L'Empire romain, Paris 1918. 
